\title{
The Influence of Leadership and Organizational Culture on Sharia-Based Business Development in Washliyin in North Sumatera
}

\author{
Burhanuddin*, Alfi Amalia, Abdul Latif, and Irvan Murizal \\ Universitas Muslim Nusantara Al Washliyah Medan, Indonesia \\ *Corresponding author email: burhanuddin@umnaw.ac.id
}

\begin{abstract}
This study aims to determine how the influence of leadership and organizational culture on sharia-based business development among Washliyun North Sumatra, which includes economic, educational, and social enterprises. The research method used is qualitative research methods, while the data collection techniques used are field research which includes observation and interviews, as well as literature. The results of this study indicate that on the one hand, leadership has a positive effect on the development of sharia-based businesses among Washliyun, North Sumatra, for example, has been able to make new innovations by establishing an Islamic bank PT. BPR Syariah Al-Washliyah like never before. But on the other hand, there are still weaknesses in leadership, for example not being able to enforce regulations according to the demands of the AD/ART AW, as a result Washliyun has not been able to have an orderly organization and an orderly administration. For example, there was a business that was not well managed so that it did not work and eventually closed, namely the Al-Washliyah hospital/clinic in 2004. Then there has been a shift in organizational cultural values, for example a decline in clerical traditions, and entered into the leadership elite structure of individuals. practical politician. This has also influenced the development of shia-based businesses in Washliyun, North Sumatra Province. This means that if leadership and organizational culture among Washliyun can be applied according to the characteristics of leadership and Islamic organizational culture, where leadership is divine and has a sharia entrepreneurial spirit, it will not only be a developing business but can bring prosperity to the people.
\end{abstract}

\section{Keywords: Leadership, Organizational Culture, Sharia-Based Business Development}

\section{INTRODUCTION}

The phenomenon of Islamic social organizations (mass organizations) that have grown from time to time is generally still unable to be economically independent. One of the Islamic mass organizations referred to is AlJam'iyatul Washliyah. Al-Washliyah is the largest Islamic community organization in North Sumatra Province, and the third largest in Indonesia after NU and Muhammadiyah. There is no doubt about the progress and existence of NU, Muhammadiyah, and Al-Washliyah as the largest mass organizations in Indonesia. Through various charitable businesses, for example in the education and social sectors (hospitals/health clinics and orphanages) NU, Muhammadiyah, and Al-Washliyah has been able to increase its strategic role in improving the welfare of the people. However, from an economic perspective, it cannot be denied that this organization is still not optimal [1]-[5]. The progress and existence of Al-Washliyah as the largest Islamic organization in North Sumatra Province and the third largest in Indonesia, where this can be seen through the various charities of Al-Washliyah in North Sumatra Province in the fields of education, social charity and economy, has been able to increase its role. strategic for 
improving the welfare of the people. From the three business fields, from the economic point of view, it cannot be denied that the role of Al-Washliyah is still not optimal. At least the principles of Islamic economics that have been suggested cannot be implemented in everyday life.

If Washliyun can implement the sharia-based business properly, it will bring prosperity to the people, especially for the Washliyun of North Sumatra Province. Since AlWashliyah is the largest Islamic organization in North Sumatra, which was born in Medan, it is fitting that it will benefit business development, to become the largest of its kind. In fact, this is not the case, even though in terms of the management of Al-Washliyah, it can be found in 27 cities/regencies of North Sumatra from the total number of cities/regencies in North Sumatra. However, there are still other mass organizations of a kind in North Sumatra that have more business units than Al-Washliyah's [6]-[10]. Therefore, in the future Washliyun must conduct introspection and reorientation so that he can be more able to do more, especially related to improving the welfare of the people. One of the fundamental challenges facing AlWashliyah Islamic organizations in the future is orientation to improve the welfare of the people. Although it must be admitted that handling this problem is not easy, because there are many factors that can influence the development of sharia-based businesses, both internal and external [11]-[15]. Internal factors include: organization, administration, management, leadership, Islamic economic motivation, assets, organizational culture, interests, and understanding.

\section{METHODOLOGY}

The research conducted is classified as field research. Therefore, the object of research is an object in the field that is able to provide information about research studies. In this case Washliyun, North Sumatra Province, is the object of research with a focus on the influence of leadership and organizational culture on sharia-based business development. This type of research is a type of qualitative research using a phenomenological approach, through: a) persistence of observations, b) triangulation of data, and c) adequacy of reference.

\section{RESULT AND DISCUSSION}

\section{Washliyin Business Charity Period 1930-1985 (When $P B A W$ Position in Medan)}

Washliyin's main business charities are da'wah, education, and social. Washliyun calls these three businesses ittifaq charity. This has a basis, namely in accordance with the situation and conditions that underlie the birth of Al-Washliyah itself, so that da'wah, education, and society become the three main pillars of the development of Al-Washluyah.

\section{Washliyin Business Charity Period 1986-present (After PB AW's Position Moved to Jakarta)}

One of the important decisions of the 1986 Al-Washliyah Congress in Jakarta is changing the position of the Grand Board of Al Jam'iyatul Washliyah

from Medan to the capital city of Jakarta. Then another important decision was to increase the type of AlWashliyah's existing charity business, namely establishing a sharia financial institution. During 1991 to 2019, the Al-Washliyah organization of North Sumatra has been led by its best cadres and has undergone several changes since the position of the Executive Board moved to Jakarta in 1986, as presented in Table 1.

In the field of education, Al-Washliyah, North Sumatra, provides religious and general education from Kindergarten (TK) to Higher Education (PT) levels. Meanwhile, the Al-Washliyah (North Sumatra) business sector established 9 orphanages and an Al-Washliyah hospital. Table 2 presents about Al-Washliyah's North Sumatra charity business below.

Table 1 The Chairman and Secretary Al-Washliyah Organization of North Sumatra

\begin{tabular}{ccll}
\hline \multirow{2}{*}{ No } & \multirow{2}{*}{ Period } & \multicolumn{1}{c}{ Regional Leadership } \\
\cline { 3 - 4 } & & \multicolumn{1}{c}{ Chairman } & \multicolumn{1}{c}{ Secretary } \\
\hline 1 & $1989-1997$ & Drs. H. Usman Serawi, LC & Ikhyar Hasibuan, BA \\
2 & $1998-2003$ & Drs. H. Abdul Halim Hrp. & H. Dariansyah Emde, S.Pd \\
3 & $2003-2005$ & Drs. H. Abdul Halim Hrp. & Drs. H. Rijal Sirait \\
4 & $2006-2010$ & Drs. H. Muhammad Nizar Syarif & Drs. H. Rijal Sirait \\
5 & $2011-2015$ & Drs. H. Hasbullah Hadi, MH & Drs. H. YulizarParlagutan, M.Si \\
6 & $2015-2020$ & Prof. Dr. H. Syaiful Akhyar Lubis, MA & H. Isma Fadli Ardya Pulungan, S.Ag, SH, MH \\
\hline
\end{tabular}


Table 2 Al-Washliyah Business Charity, North Sumatra, 2003

\begin{tabular}{|c|c|c|}
\hline No & Charity Enterprises & Quantity \\
\hline 1 & $\begin{array}{l}\text { Organization Field: } \\
\text { Regional Leaders }\end{array}$ & $\begin{array}{l}26 \text { Regional Leaders } \\
\text { from } 33 \\
\text { cities/districts-SU }\end{array}$ \\
\hline 2 & $\begin{array}{l}\text { Primary and Secondary } \\
\text { Education Sector: } \\
\text { Public school } \\
\text { Religion school } \\
\text { Other Education } \\
\text { Higher Education Sector: } \\
\text { University } \\
\text { High School }\end{array}$ & $\begin{array}{l}148 \text { pieces } \\
461 \text { pieces } \\
76 \text { pieces }\end{array}$ \\
\hline 3 & $\begin{array}{l}\text { Economics: } \\
\text { Sharia Bank Rural Bank } \\
\text { (BPR) }\end{array}$ & 1 piece \\
\hline 4 & $\begin{array}{l}\text { Social Field: } \\
\text { Hospital/Clinic } \\
\text { Orphanage }\end{array}$ & $\begin{array}{l}1 \text { piece } \\
9 \text { pieces }\end{array}$ \\
\hline
\end{tabular}

Source: AW SU

However, over time this organizational dynamic has occurred, so that based on the latest data on the AlWashliyah charity, North Sumatra, there have been ups and downs, it can be seen in Table 3 below.

Table 3 Al-Washliyah Business Charity, North Sumatra, 2018

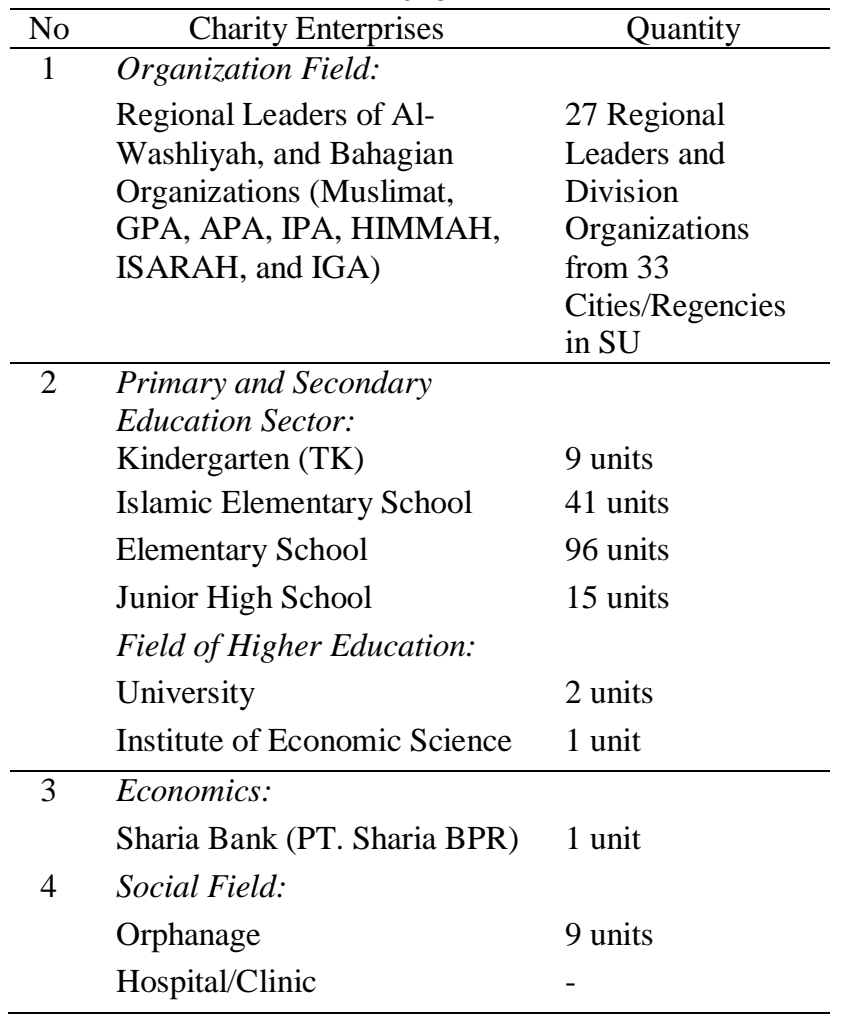

Source: AW SU
It can be said that the back and forth of an organization is determined or influenced by the leadership and organizational culture. It can be said that the back and forth of an organization is also determined or influenced by the leadership and organizational culture.

The influence of leadership on business. Leadership can influence the development of a business. According to Ordway Tead, leadership is an activity of influencing people to be willing to work together to achieve some of the goals they want. Leadership is likened to a tool or means to influence a person or group of people to be willing to do something voluntarily, as planned at the beginning of the thought of a leader himself. A leader will be required to continuously come up with creative ideas so that the business he runs can improve his performance in all fields and can survive or adapt to environmental changes. In essence, leadership is the process of influencing or setting an example from leaders to followers in an effort to achieve organizational goals.

Leadership is closely related to the power of the leader in obtaining the tools to influence the behavior of his followers. In carrying out his activities the leader is influenced by various factors. These factors are as stated by Reitz in Fattah [16], as follows.

1) Personality, past experiences and expectations of leaders, this includes values, background and experiences will affect the choice of leadership style.

2) Expectations and behavior. Most people consider a leader as a source of influence, because basically a leader influences follower or as a party who is influenced [17]. What is meant by leadership in this context is Islamic leadership, which is the activity of guiding, guiding, guiding and showing the path of pleasure. Allah SWT. So, the main orientation in Islamic leadership is the pleasure of Allah.

The influence of organizational culture on business. Organizational culture can influence the development of a business. Apart from creating a relationship between leadership and employees, another factor that is most sensitive and can affect business development is organizational culture. The role of organizational culture for business development, the basic concept that is the foundation of Islamic economics can be used as a basis for work culture as an organizational culture.

Organizational culture can be a major competitive advantage instrument, when organizational culture supports organizational strategy and can respond to or overcome environmental challenges quickly and appropriately. So, through organizational culture a leader can monitor employee behavior, the cooperation that is created, how they think and how they interact with their environment. If the organizational culture is good, it will be able to increase employee performance and performance and contribute success to business development. Of course, what is meant is a positive organizational culture towards business development based on Shari'a guidelines. This shows that organizational culture greatly influences a business. 


\section{CONCLUSION}

Leadership is an important aspect that influences shariabased business development among Washliyin North Sumatra, both for planning to start a business, developing a business, as well as the process of handling internal and external activities involving members/employees and other related parties. The leadership here is still not maximal to be able to develop Al-Washliyah's efforts.

There is organizational culture in the Washliyin community of North Sumatra. It has changed from previously dominated by clerical traditions, for example, now it has entered from the elements of politicians in leadership. This situation certainly affects the organizational culture. And this can have a positive or negative effect on the development of sharia-based businesses in the economic, educational, and social sectors of Washliyun, North Sumatra Province.

\section{REFERENCES}

[1] F. Darus, N. H. A. Shukri, H. Yusoff, A. Ramli, M. M. Zain, N. A. A. Bakar, Empowering social responsibility of Islamic organizations through Waqf. Research in International Business and Finance, 42 (2017), 959-965.

[2] M. Peucker, R. Ceylan, Muslim community organizations - sites of active citizenship or selfsegregation?. Ethnic and Racial Studies, 40 (14) (2017), $2405-2425$.

[3] P. C. Saidalavi, Muslim Social Organisation and Cultural Islamisation in Malabar. South Asia Research, 37 (1) (2017), 19-36.

[4] L. M. Ifada, I. Ghozali, F. Faisal, Islamic Organizational Culture, Islamic Corporate Social Responsibility, and Corporate Performance: Evidence from Sharia Bank in Indonesia. International Journal of Financial Research, 10 (6) (2019), 118-123.

[5] R. Eseed, Social Service Provision by Minority Religious Organizations: A Case Study of the Islamic Movement in Kafr Qassim. Journal of Social Policy, 49 (3) (2020), 507-524.

[6] J. Ja'far, Peran Al Jam'iyatul Washliyah dalam Merevitalisasi Madhhab Shafi'i di Era Kontemporer. Justicia Islamica, 13 (1) (2016), 1-21.

[7] J. Ja'far, Khazanah Kitab Kuning di Madrasah Al Jam'iyat Al Washliyah. Jurnal Pendidikan Agama Islam Al-Thariqah, 2 (2) (2017), 124-134.

[8] Ja'far, Al Jam'iyatul Washliyah dan Problem Kepemimpinan Non-Muslim dan Perempuan. AHKAM, 17 (2) (2017), 413-434.
[9] Ja'far, Respons Al Jam'iyatul Washliyah terhadap Terorisme. AKADEMIKA Jurnal Pemikiran Islam 22 (1) (2017), 1-26.

[10] L. Hanum, Perempuan di Lembaga Pendidikan Al Jam'iyatul Washliyah. Journal of Contemporary Islam and Muslim Societies, 2 (1) (2018), 29-49.

[11] M. N. Yasin, The Pluralism of Islamic Economic Law: Dialectic of Moslem and non-Moslem in the Development of Sharia Banking in Indonesia. Journal of Indonesian Islam, 10 (1) (2016), 113-138.

[12] Meirison, The Development of Islamic Economics in Various Parts of The World. Jurnal Ekonomi dan Bisnis Islam, 2 (2) (2017), 197-206.

[13] S. Yasen, Internalization of Balance and Justice Value Sharia Economic System in Indonesia, Jurnal Hukum Ekonomi Syariah, 2 (2) (2018), 80-94.

[14] A. S. Rusydiana, F. F. Hasib, Islamic Banking Selection Criteria: Case in Indonesia Using Analytic Network Process. Economica: Jurnal Ekonomi Islam, 10 (1) (2019), 165-188.

[15] A. P. Pratama, H. S. Disemadi, P. Prananingtyas, Existence and Position of Islamic Economic Laws in Indonesia. Legality, 27 (2) (2019/2020), 222-231.

[16] N. Fattah, Landasan Manajemen Pendidikan, Bandung: Rosdakarya, 1996.

[17] Rivai, Kepemimpinan dan Prilaku Organisasi, Jakarta: Rajawali Pers, 2012. 